\title{
Biological and ecological aspects of Bathygobius soporator (Valenciennes, 1837) (Perciformes, Gobiidae) from Santa Catarina, Southern Brazil
}

\author{
Germano Henrique Costa Barrilli ${ }^{1,3}$; Julia Gomes do Vale ${ }^{1,4}$; Gabriela Stahelin ${ }^{2,5}$ \& Joaquim Olinto Branco ${ }^{1,2,6}$ \\ 1 Universidade Federal de São Carlos (UFSCAR), Centro de Ciências Biológicas e da Saúde (CCBS), \\ Programa de Pós-Graduação em Ecologia e Recursos Naturais (PPGERN). São Carlos, SP, Brasil. \\ 2 Universidade do Vale do Itajaí (UNIVALI), Escola do Mar, Ciência e Tecnologia. Itajaí, SC, Brasil. \\ 3 ORCID: http://orcid.org/0000-0001-8625-2759. E-mail: germanohcb@gmail.com (corresponding author) \\ ${ }^{4}$ ORCID: http://orcid.org/0000-0002-9510-1052. E-mail: julia.gvale@hotmail.com \\ ${ }^{5}$ ORCID: http://orcid.org/0000-0001-9661-6560. E-mail: gabrielastahelin@univali.br \\ ${ }^{6}$ ORCID: http://orcid.org/0000-0002-3521-1671.E-mail: branco@univali.br
}

\begin{abstract}
Bathygobius soporator (popularly known as "Maria da toca") is a species that, although abundant, is little studied in aspects regarding growth, feeding and reproduction in southern Brazil. Studies on trophic ecology still raise questions on the species' actual diet, especially in the context of algae participating as a food resource or an accidental intake. Thus, this study aims to fill this gap, evaluating the growth, feeding, and reproduction of this species. Monthly samples from two periods (1997-1998 and 2005-2006) were analyzed for growth, feeding, and reproduction parameters, totalizing 1177 individuals evaluated. Our results demonstrate that Bathygobius soporator is a species of fast development, reaching the age of first maturation before the first year of life. It presents a sexual dimorphism, being males larger than females. Reproductive peaks occur in the spring and summer months. The species presented a broad trophic spectrum, including algae as the main food resource, not just an accidental intake. The omnivorous-opportunistic trophic ecology of this species is emphasized, agreeing with the information of previous studies.
\end{abstract}

Keywords. Goby; Algae; Growth; Fish; Trophic ecology.

\section{INTRODUCTION}

Estuarine environments are known to be environments with high habitat heterogeneity and, therefore, they have a great diversity of fish species (Paiva et al., 2008) that seek protection and nesting areas. Among these fishes, the family Gobiidae is represented by about 240 genera and more than 2000 species (Nelson et al., 2016), contributing to the greatest diversity among tropical and subtropical marine fishes (Zanlorenzi \& de Tarso Chaves, 2011). The gobiid species Bathygobius soporator (Valenciennes, 1837 ) is a common inhabitant of the estuaries, mangroves, coral reefs and rocky environments of the American Atlantic coast (Soares et al., 2016). Although abundant on the Brazilian coast, studies involving the population dynamics of this species in natural environments are scarce, mostly due to the difficulties of its sampling with conventional fishing artifacts (Kovacic, 2007).
Bathygobius soporator's feeding ecology indicates that the species presents a broad trophic spectrum, classified as an opportunistic predator (omnivorous diet) on the coast of Rio de Janeiro (Nascimento \& Peret, 1986) and Bahia (Lopes \& Oliveira-Silva, 1998), with a tendency to crustacean-eating and accidental ingestion of algae on the coast of Pará (Soares et al., 2016). However, there is no consensus among studies on whether algae intake is accidental or part of this species' diet. Studies show that algae ingestion is a consequence of the species' pre-reproductive behavior, since males cleanse the nest area through ingestion of algae and other debris, which may explain the occurrence of macroalgae as stomach contents in males of B. soporator (Tavolga, 1954; Soares et al., 2016).

Information on the biology of $B$. soporator in southern Brazil, whenever available, is still restricted mostly to reports and monographs. Thus, this paper aims to fill this gap by studying B. soporator 
from the coast of the Santa Catarina state - Brazil, where data from two periods were used to evaluate the species' growth, feeding, and reproduction.

\section{MATERIAL AND METHODS}

\section{Study area}

Fishes were sampled on the Saco da Fazenda ecosystem, which is an artificial estuarine habitat resulting from years of human encroachment and harbor interventions. Water renewal is restricted. The substrate is typically formed by clay, silicium muds and sand, presenting a maximum depth of 2 meters except for the canal leading up the river, where it exceeds 9 meters. Tidal amplitudes usually are lower than $1.4 \mathrm{~m}$ and the annual rainfall averages between 1250 to $1500 \mathrm{~mm}$ (Manoel et al., 2011).

\section{Specimens collection and processment}

Specimens of Bathygobius soporator were sampled monthly between July/1997 to April/1998 and June/2005 to March/2006 in the piers of Saco da
Fazenda. The samples come from environmental monitoring work, a consequence of the expansion of the pier. Samples were standardized in the early morning and at low tide. The collection equipment consisted of rods with reels armed with nylon lines and hook 14 $(1.8 \mathrm{~cm} \times 0.5 \mathrm{~cm})$, baited with shrimp and operated by three fishermen for 60 minutes. The individuals were stored in numbered plastic bags, labeled and kept in cool boxes with an ice cube.

Once in the laboratory, all fish were adequately identified according to Menezes \& Figueiredo (1985). Sexing was made through macroscopic gonad observation and the morphology of the anal fin (Tavolga, 1954). Total length $(\mathrm{cm})$ and humid weight $(\mathrm{g})$ were determined as well as a macroscopic gonad characterization (weight and maturation), according to Vazzoler (1996).

The stomachs were removed, weighed, and classified into five categories, according to a previously established scale, indicating the repletion degree: 1 = empty stomach, 2 = quarter-full stomach, 3 = half-full stomach, $4=$ three quarters full stomach and $5=$ full stomach (Sabinson et al., 2015). Contents were then removed with water and placed in Petri dishes. The identification of food items was made with the specialists' assistance. Unidentified items due to high digestion levels were categorized simply as organic matter.
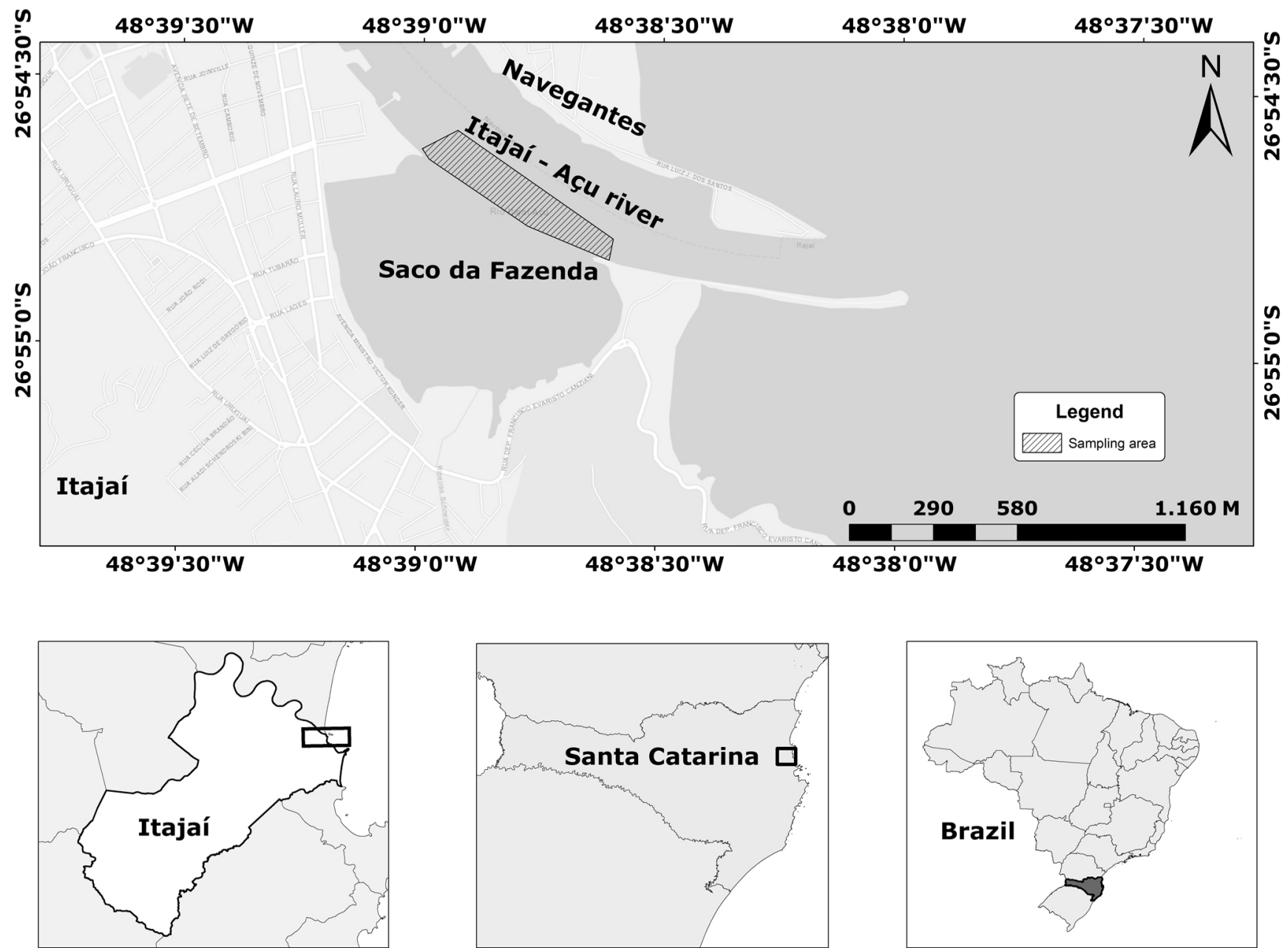

Figure 1. Location of the sampling area (hatch area) at the Itajaí-açu river (Saco da Fazenda), the coast of Santa Catarina, Brazil. 

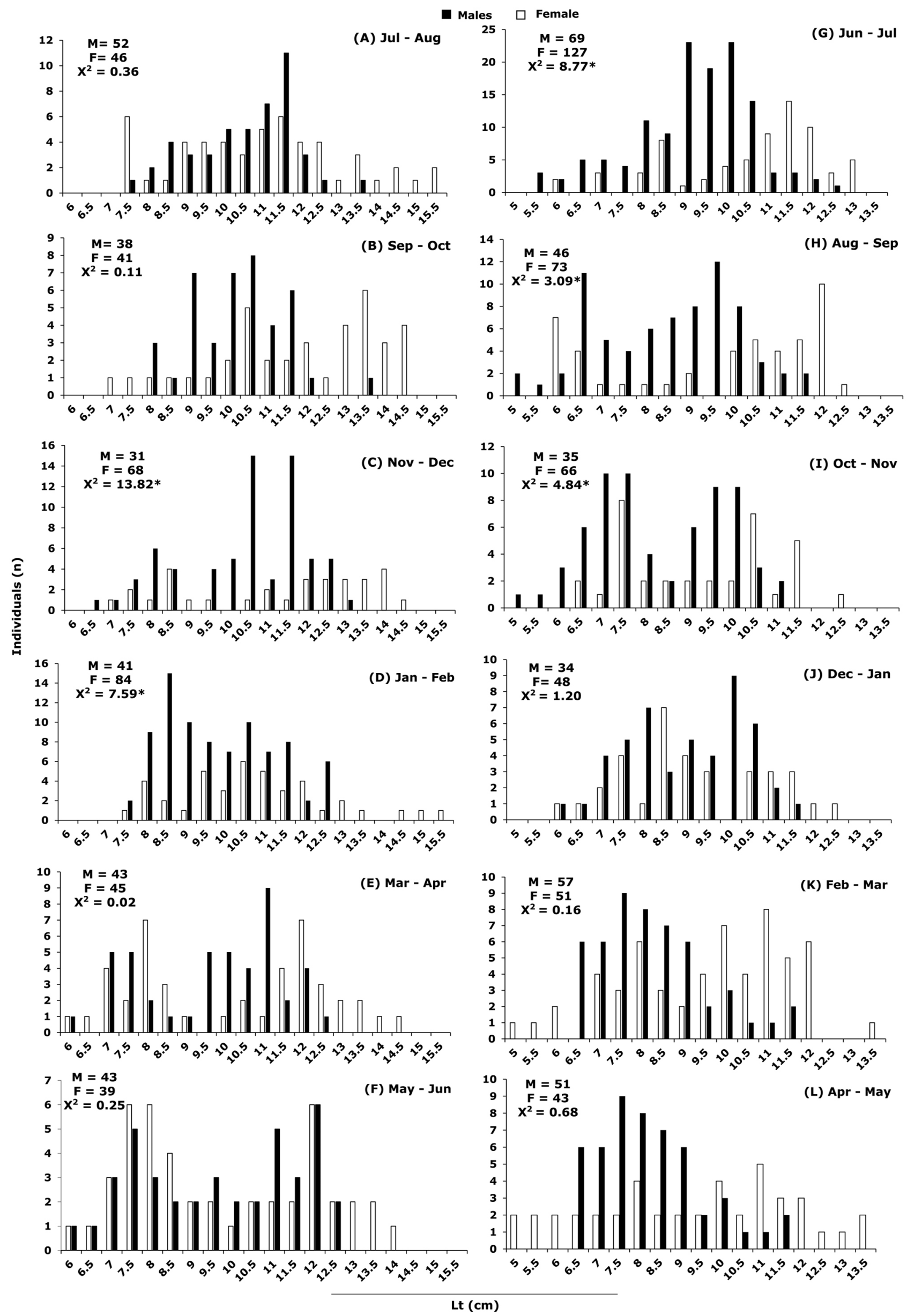

Figure 2. Number of individuals ( $\mathrm{n}$ ) of the Bathygobius soporator species in the size classes. * significant for $X^{2}$ test with 1 degree of freedom. 


\section{Data Analysis}

Weight and length from fishes collected in both years were used to adjust the growth curves (length/weight relationships) for each sex by the equation $\mathrm{W}=\mathrm{aLt}^{\mathrm{b}}$ (Le Cren, 1951), where "W" corresponds to weight, "a" curve intercept, "Lt" total length, and " $b$ " angular coefficient or allometric coefficient. In order to assess whether there is a difference in sex ratio in the population $\mathrm{X}^{2}$ test (Chi Square - test) was applied, at each sampling, for a significance level of $0.05 \%, n-1$ freedom degrees $(n=2)$ and in 1:1 ratio. Growth curves for length in both periods were obtained from the absolute frequency distribution for males and females:

$$
L t=L \infty\left[1-e-k\left(t-t^{0}\right)\right](\text { von Bertalanffy, 1938) }
$$

where: $L t=$ total length for age $t$ in $\mathrm{cm} ; \mathrm{L} \infty=$ maximum estimated average length in $\mathrm{cm}$; $\mathrm{e}=$ neperian logarithm base; $\mathrm{k}=$ growth rate constant; $\mathrm{t}=$ age of fish in months and $\mathrm{t}^{0}=$ length at birth.

Average size in first sexual maturation $\left(\mathrm{L}^{50}\right)$ and von Bertalanffy's curve parameters were estimated by the Ford-Walford method (Santos, 1978). Gonado-somatic índex (GSI) was calculated by the standard reason between gonadic weights $(\mathrm{Wg})$ for the specimen's total weight (Wt) (Vazzoler, 1996). For the diet's quali-quantitative analysis in both time periods (1997/1998 and 2005/2006), both the volumetric and occurrence frequency methods were applied (Hynes, 1950; Berg, 1979), and complemented by the modified feeding index from Kawakami \& Vazzoler (1980). This contributed to a global understanding of $B$. soporator's diet and made
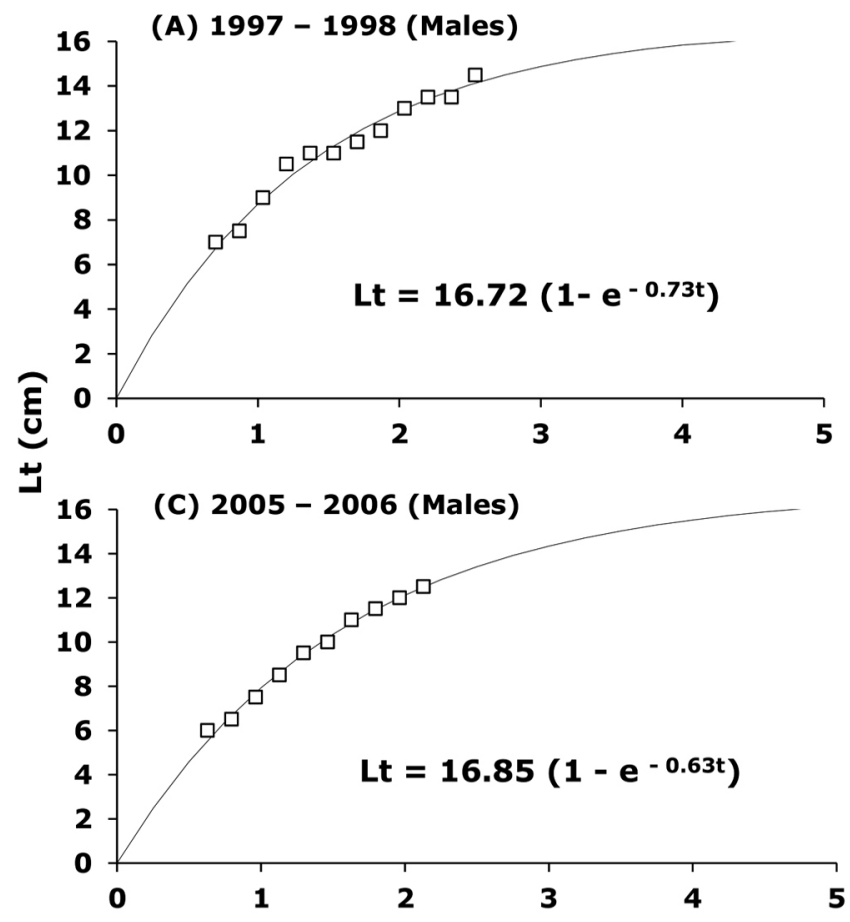

possible to compare our data with those from other species as well as the predator/prey inter-relationship. The Permutational multivariate analysis of variance PERMANOVA 9999 permutations (Anderson, 2001) was also applied to test if the composition and abundance of food items showed differences between sexes and time periods, with the Bray-Curtis method and using the statistics package Palaeontological Statistics Software Package v. 3.14 (Hammer et al., 2001).

\section{RESULTS}

A total of 528 fish were collected during the 1997-1998 period (Figs. 2A-2F), with males represented by $38.8 \%$ and females by $61.2 \%$ of individuals. The total length varied between 6.30 and $15.80 \mathrm{~cm}(11.25 \pm 2.19 \mathrm{~cm})$ for males, and between 6.20 and $13.80(10.28 \pm 1.47 \mathrm{~cm})$ for females. Females dominated significantly in November - December and January - February samplings $\left(X^{2}\right.$ test, f.d $=1$ ). Considering the total collected during the 1997-1998 period, females were significantly more numerous than males $\left(X^{2}=27.37, f . d=1\right)$, resulting in a sex ratio of 1.57: 1 .

During the 2005-2006 period (Figs. 2G-2L), a total of 649 fish were collected, of which $45.0 \%$ were males and $55.0 \%$ females. Total lengths varied from 5.0 to $13.8 \mathrm{~cm}(9.98 \pm 2.00 \mathrm{~cm})$ for males, and from 5.3 to $12.5(8.85 \pm 1.47 \mathrm{~cm})$ for females. Females were statistically more numerous than males in July - August and October - November samples $\left(X^{2} ; f . d=1\right)$. Considering the total collected during the 2005-2006 period, females were again significantly more numerous than males $\left(X^{2}=94.58 ; f . d=1\right)$, resulting in a sex ratio of 1.22: 1 .
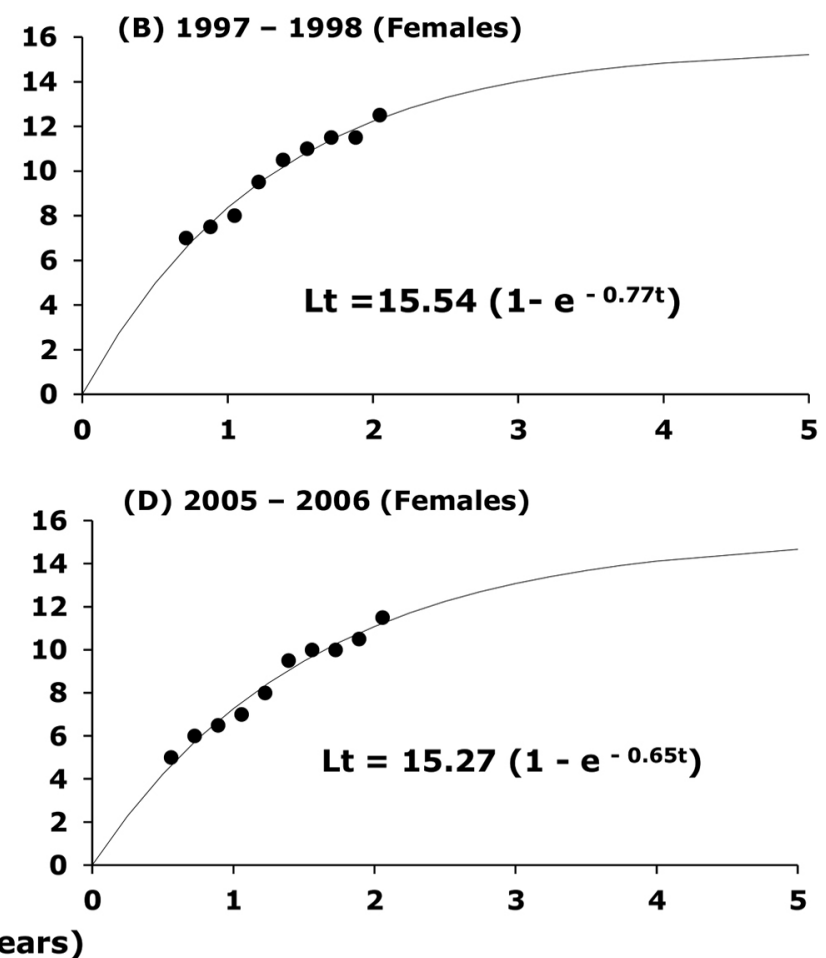

口 Male's observed values • Female's observed values

Figure 3. Growth curves for both time frame and both sexes of the Bathygobius soporator. 


\section{Growth Data}

The von Bertalanffy's growth curves are shown in Fig. 3. Males produced $L \infty$ values ranged between 16.72 and $16.85 \mathrm{~cm}$, and $\mathrm{k}$ values between 0.73 and 0.63 , respectively, for 1997/1998 and 2005/2006 periods (Figs. 3A, C). In females, the $L_{\infty}$ values varied between 15.54 and $15.27 \mathrm{~cm}$, and k values, between 0.77 and 0.65 for, respectively, 1997-1998 and 2005-2006 periods (Figs. 3B, D).

The " $b$ " values obtained by the length-weight relationship for the period 1997/1998 was $2.99 \pm 0.03$ (males) and did not differ from $3.0(t=0.12 ; \mathrm{p}>0.05)$, thus indicating an isometric growth (Fig. 4A). As for females $(b=2.93 \pm 0.04)$ values were significantly lower than 3.0 ( $t=30.481 ; p<0.05$ ), thus pointing towards a negative allometric growth (Fig. 4B). Significant b values differences $(t=13.63 ; p<0.05)$ have also been observed in 2005-2006 period for males $(2.97 \pm 0.10)$ and females $(2.90 \pm 0.04)$, with values lower than 3.0 , characterizing a negative allometric growth for both sexes.

\section{Reproduction data}

In the 1997-1998 period, a total of 201 gonads from male individuals were analyzed, which are represented by mature $(66 \%)$ and immature $(34 \%)$ organs. The mature gonads varied from 0.01 to $0.11(0.04 \pm 0.02 \mathrm{~g})$ for immature fish; and from 0.01 to $0.64 \mathrm{~g}(0.14 \pm 0.10 \mathrm{~g})$ for adults. For the 285 females from that same period, 34\% of the gonads were immature and $66 \%$ were mature. Immature organs varied between 0.01 and $2.15 \mathrm{~g}(0.40 \pm 0.38 \mathrm{~g})$,

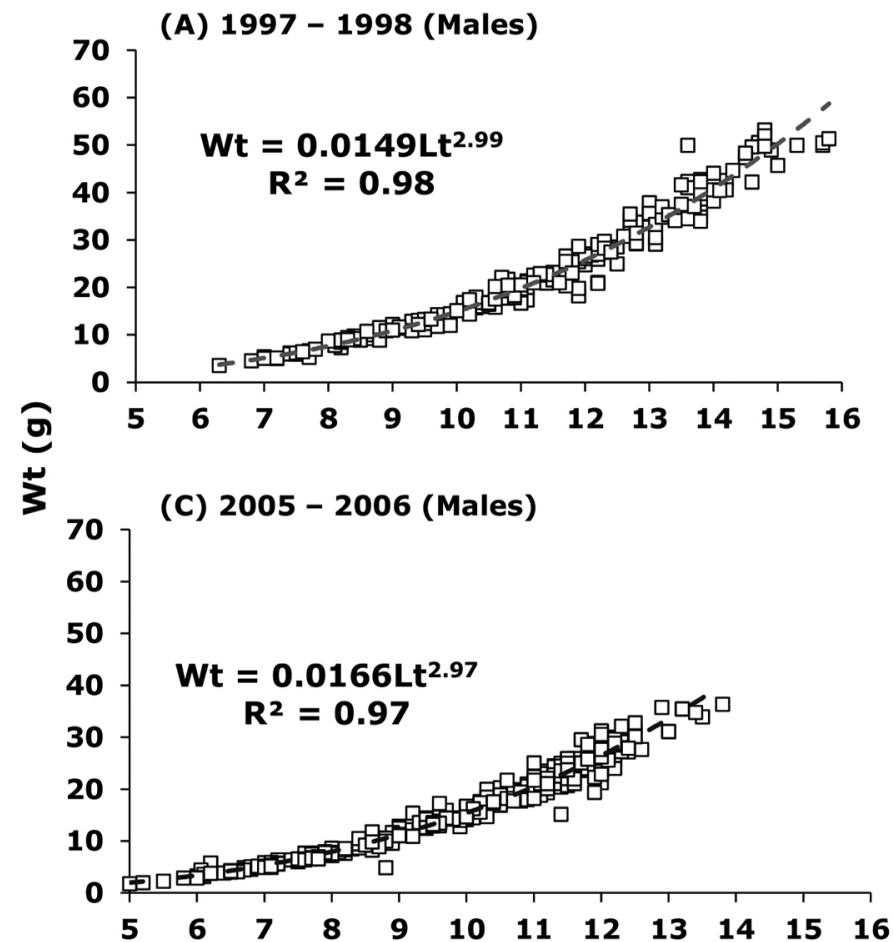

while mature ones presented values ranging from 0.02 to $3.95 \mathrm{~g}(1.19 \pm 0.86 \mathrm{~g})$.

For the $2005-2006$ period $81 \%$ of the gonads were immature and $19 \%$ mature, considering the 190 males analyzed. The gonadal weight ranged from 0.01 and $0.19(0.04 \pm 0.04 \mathrm{~g})$ for the immature and from 0.02 to $0.80 \mathrm{~g}(0.10 \pm 0.10 \mathrm{~g})$ for the mature. Of the 410 females from the same period, the immatures represented $80 \%$ and the mature $20 \%$. Immatures ranged from 0.01 to $1.34 \mathrm{~g}(0.15 \pm 0.20 \mathrm{~g})$, while mature between 0.02 and $2.72 \mathrm{~g}(0.60 \pm 0.55 \mathrm{~g})$.

The first maturation size $\left(L_{50}\right)$ was higher for males in both periods (Fig. 5), when compared to females. The estimated values for both sexes in 1997-1998 were $10.62 \mathrm{~cm}$, for males, and $8.32 \mathrm{~cm}$ for females (Figs. 5A, 5B). For the 2005-2006 data (Figs. 5C, 5D), the values were $10.31 \mathrm{~cm}$ (males) and $8.00 \mathrm{~cm}$ (females).

Highest gonadosomatic index values for both periods, in males and females, were recorded in January (Figs. 6A, B), indicating that reproductive activity occurred in the summer months.

\section{Feeding data}

In 1997-1998 period, 489 stomach contents were analyzed (males $=201$; females $=288$ ), with food items present in $69.7 \%$ (males) and $83.7 \%$ (females) (Table 1). Of the 516 stomach contents analyzed in 2005-2006 period (males $=249$; females $=267$ ) food items were found in $38.2 \%$ of males and $70.0 \%$ of females (Table 1 ).

By analyzing the stomach contents of the specimens, it was possible to identify 38 items in the diet of $B$. sopo-
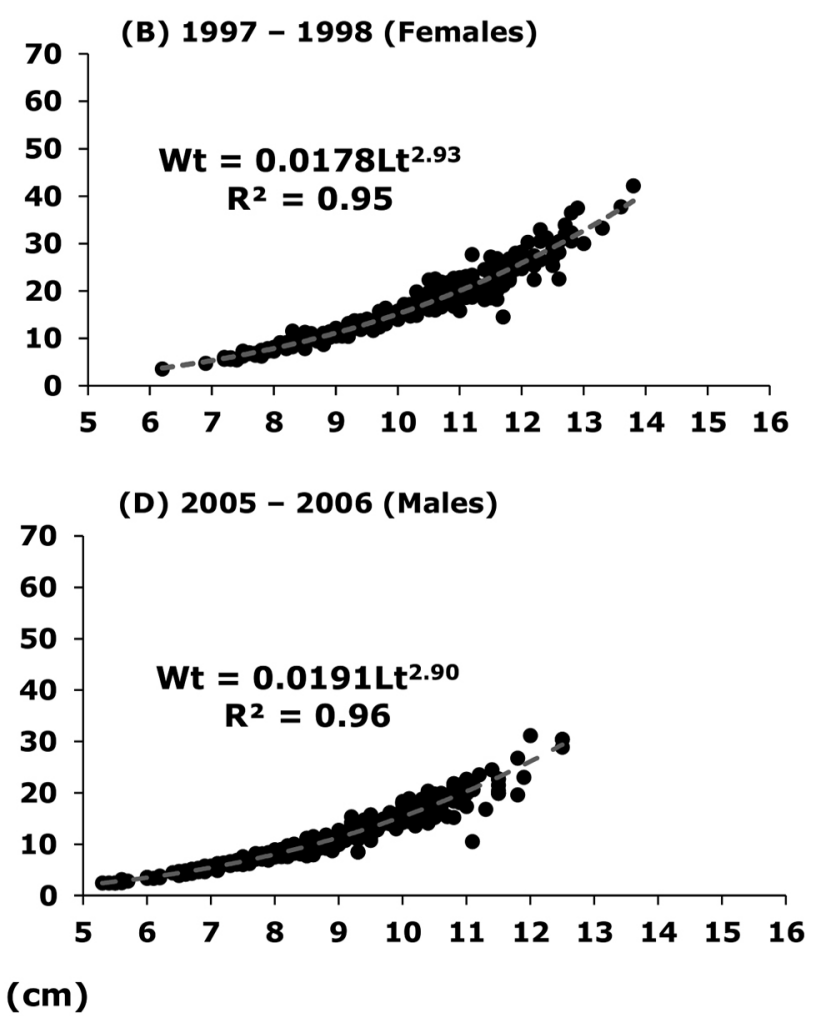

口 Male's observed values

- Female's observed values $\quad--$ - Expected values

Figure 4. Length - Weight relatioships for males (A, C) and females (B, D) of B. soporator in the 1997-1998 (A, B) and 2005-2006 (C, D) periods. 


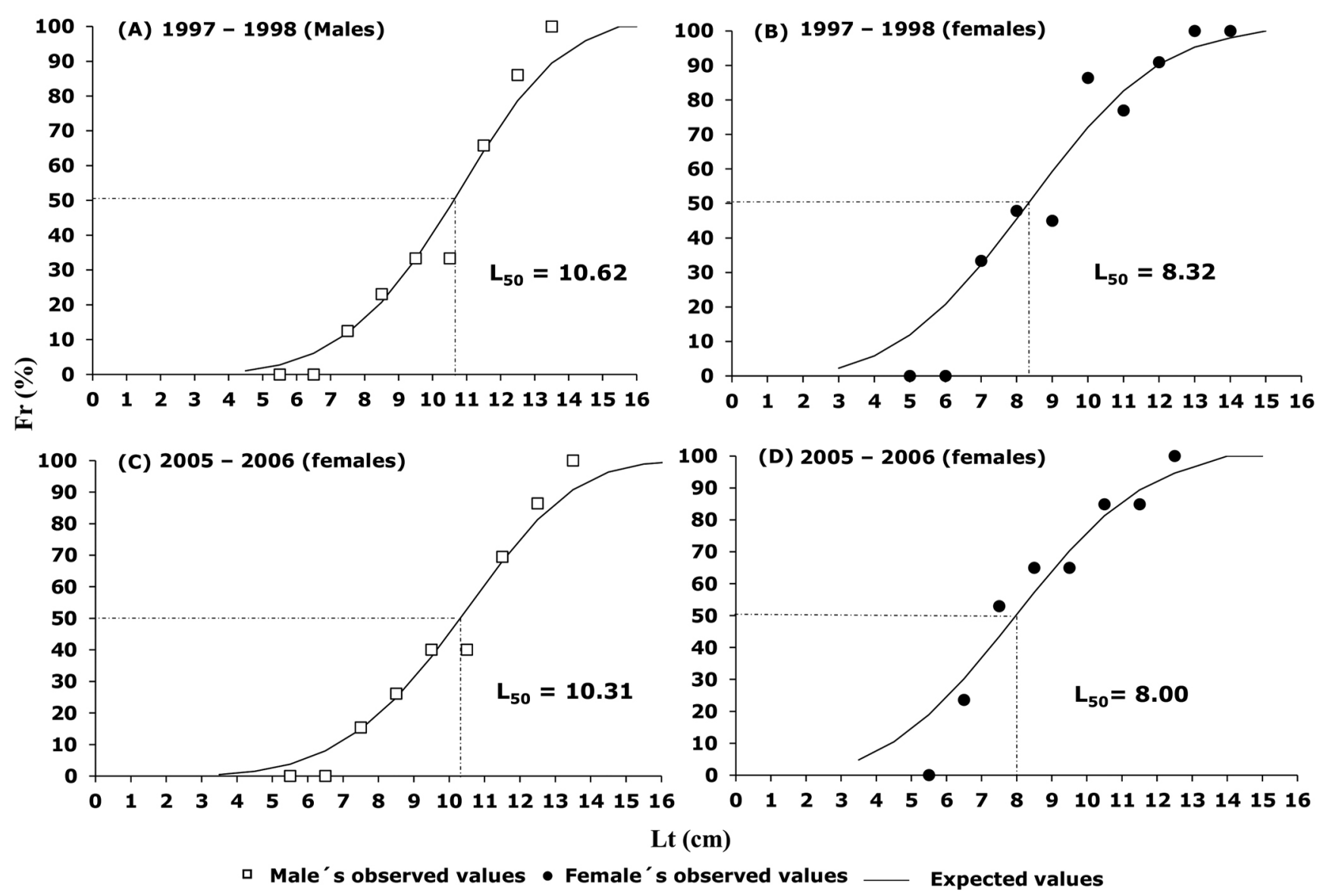

Figure 5. First maturation size $\left(L_{50}\right)$ for males and females of B. soporator collected between the 1997-1998 and 2005-2006 periods.

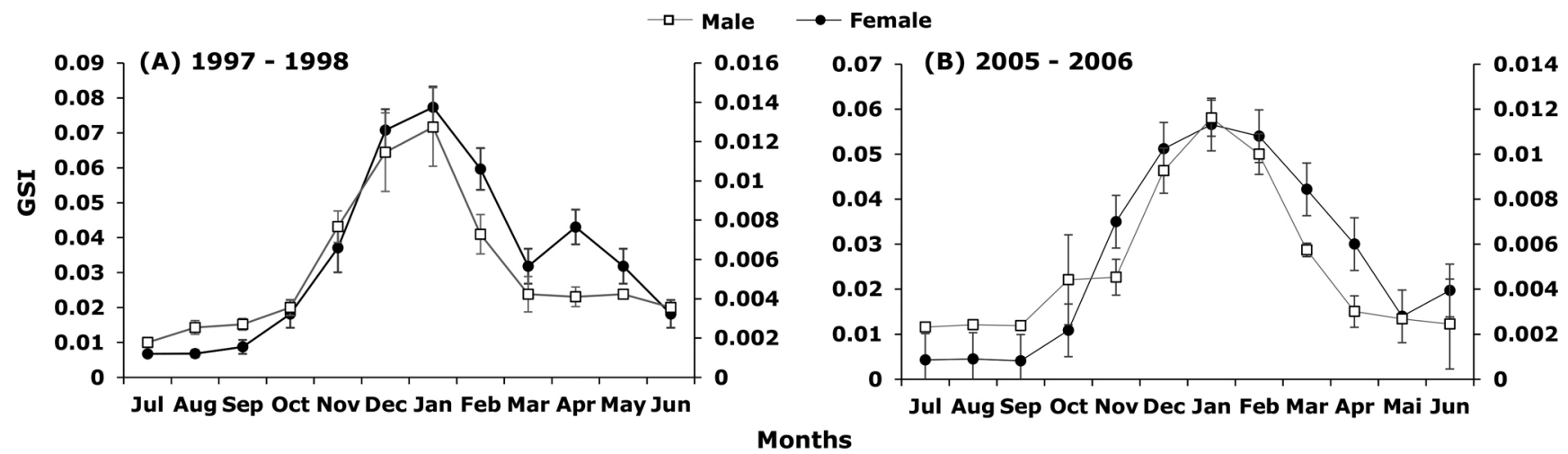

Figure 6. Gonadosomatic index (GSI) of males and females of the species B. soporator for the periods 1996-1997 (A) and 2005-2006 (B).

Table 1. Biometrics and degree repletion of Bathygobius soporator's stomachs from Saco da Fazenda, SC, Brazil.

\begin{tabular}{lcccccc}
\hline \multirow{1}{*}{ Repletion } & \multicolumn{2}{c}{ Males } & \multicolumn{4}{c}{ Females } \\
\cline { 2 - 7 } & $\begin{array}{l}\text { Stomach } \\
\text { weight(g) }\end{array}$ & Average & $\mathbf{n}$ & $\begin{array}{c}\text { Stomach } \\
\text { weight (g) }\end{array}$ & Average & $\mathbf{N}$ \\
\hline 1997-1998 & & & & & & \\
Empty & $0.04-0.69$ & $0.19 \pm 0.11$ & 61 & $0.02-1.22$ & $0.20 \pm 0.19$ & 80 \\
Quarter-full stomach & $0.02-1.07$ & $0.30 \pm 0.25$ & 54 & $0.03-1.68$ & $0.30 \pm 0.35$ & 54 \\
Half-full & $0.05-1.44$ & $0.34 \pm 0.32$ & 32 & $0.03-1.60$ & $0.28 \pm 0.25$ & 61 \\
Three quarters full & $0.08-1.26$ & $0.32 \pm 0.32$ & 17 & $0.10-0.52$ & $0.26 \pm 0.11$ & 27 \\
Full & $0.05-2.68$ & $0.55 \pm 0.47$ & 37 & $0.08-1.67$ & $0.47 \pm 0.34$ & 66 \\
\hline
\end{tabular}

\begin{tabular}{lcccccc}
\hline \multirow{1}{*}{ Repletion } & \multicolumn{2}{c}{ Males } & \multicolumn{4}{c}{ Females } \\
\cline { 2 - 7 } & $\begin{array}{l}\text { Stomach } \\
\text { weight(g) }\end{array}$ & Average & $\mathbf{n}$ & $\begin{array}{c}\text { Stomach } \\
\text { weight (g) }\end{array}$ & Average & N \\
\hline $\mathbf{2 0 0 5 - 2 0 0 6}$ & $0.12-0.28$ & $0.20 \pm 0.16$ & 154 & $0.04-0.83$ & $0.14 \pm 0.20$ & 80 \\
Empty & $0.03-0.93$ & $0.25 \pm 028$ & 16 & $0.03-1.47$ & $0.17 \pm 0.11$ & 33 \\
Quarter-full stomach & $0.05-0.49$ & $0.20 \pm 0.09$ & 43 & $0.02-0.49$ & $0.17 \pm 0.10$ & 49 \\
Half-full & $0.08-0.70$ & $0.25 \pm 0.16$ & 17 & $0.04-1.02$ & $0.29 \pm 0.28$ & 39 \\
Three quarters full & $0.33-0.40$ & $0.37 \pm 0.22$ & 19 & $0.03-1.08$ & $0.25 \pm 0.21$ & 66 \\
Full & & & & & & \\
\hline
\end{tabular}


Table 2. Relative frequency (Fi) and volume (Vi) of food items found in the stomachs of the Bathygobius soporator. Legend: $\mathrm{n}=$ number of stomachs analyzed; $n$. $\mathrm{i}=$ (not identified).

\begin{tabular}{|c|c|c|c|c|c|c|c|c|}
\hline \multirow{3}{*}{ ITENS } & \multicolumn{4}{|c|}{ 1997-1998 } & \multicolumn{4}{|c|}{$2005-2006$} \\
\hline & \multicolumn{2}{|c|}{$\begin{array}{c}\text { Male } \\
(n=201)\end{array}$} & \multicolumn{2}{|c|}{$\begin{array}{l}\text { Female } \\
(n=288)\end{array}$} & \multicolumn{2}{|c|}{$\begin{array}{c}\text { Male } \\
(n=360)\end{array}$} & \multicolumn{2}{|c|}{$\begin{array}{c}\text { Female } \\
(n=410)\end{array}$} \\
\hline & $\mathrm{Fi}$ & Vi & $\mathrm{Fi}$ & Vi & $\mathrm{Fi}$ & Vi & $\mathrm{Fi}$ & Vi \\
\hline \multicolumn{9}{|l|}{ ALGAE } \\
\hline Diatomaceas & & & & & 0.01 & & & \\
\hline \multicolumn{9}{|l|}{ CHLOROPHYTA } \\
\hline Ulva fasciata & 0.72 & 0.77 & 0.64 & 0.71 & 0.29 & 0.18 & 0.25 & 0.12 \\
\hline PHAEOPHYTA (n.i) & 0.05 & 0.01 & 0.09 & 0.02 & 0.53 & 0.51 & 0.48 & 0.66 \\
\hline Sargassum sp. & 0.01 & & 0.06 & 0.01 & & & & \\
\hline \multicolumn{9}{|l|}{ RHODOPHYTA } \\
\hline \multicolumn{9}{|l|}{ Bostrychia sp. } \\
\hline Gracilaria sp. & 0.01 & & 0.02 & & & & & \\
\hline POLYCHAETA (n.i) & 0.03 & 0.02 & 0.06 & 0.03 & 0.11 & 0.03 & 0.07 & 0.02 \\
\hline Nereidae & & & 0.01 & & 0.02 & 0.03 & & \\
\hline \multicolumn{9}{|l|}{ Oenonidae } \\
\hline Arabella sp. & 0.01 & 0.01 & & & & & & \\
\hline CRUSTACEA (n.i) & 0.01 & & & & 0.03 & & 0.01 & \\
\hline Isopoda & 0.01 & & 0.04 & 0.01 & 0.01 & 0.02 & 0.01 & 0.02 \\
\hline Brachyura & 0.01 & & 0.02 & 0.01 & & & & \\
\hline \multicolumn{9}{|l|}{ Caprellidae } \\
\hline Caprella sp. & & & 0.01 & & 0.03 & & & \\
\hline Gamaridae & 0.08 & 0.01 & 0.09 & 0.02 & 0.08 & 0.01 & 0.08 & 0.01 \\
\hline \multicolumn{9}{|l|}{ Grapsidae } \\
\hline Pachygrapsus transversus & & & 0.02 & 0.02 & 0.02 & & & \\
\hline \multicolumn{9}{|l|}{ Paguridae } \\
\hline Pagurus sp. & & & 0.01 & & & & & \\
\hline \multicolumn{9}{|l|}{ Panopeidae } \\
\hline Euripanopeus sp. & & & 0.01 & & 0.01 & 0.01 & 0.02 & 0.02 \\
\hline Pinotheridae & & & 0.01 & & & & & \\
\hline Porcelannidae & 0.01 & & 0.01 & & & & & \\
\hline Callinectes sp. & & & 0.01 & & & & 0.04 & \\
\hline Petrolisthes armatus & 0.01 & 0.00 & 0.02 & 0.03 & 0.01 & 0.01 & & \\
\hline Petrolisthes galatinus & 0.01 & 0.01 & & & & & & \\
\hline \multicolumn{9}{|l|}{ Sergestidae } \\
\hline Acetes americanos & & & 0.03 & 0.01 & 0.02 & & & \\
\hline Xanthidae & & & 0.01 & & 0.01 & 0.01 & & \\
\hline Hexapanopeus sp. & 0.01 & 0.01 & 0.01 & 0.01 & & & & \\
\hline Menipi nodifrons & & & 0.01 & 0.01 & & & & \\
\hline Ostracoda & & & 0.01 & & & & & \\
\hline BIVALVIA (n.i) & 0.03 & 0.00 & 0.01 & & 0.01 & & 0.02 & 0.02 \\
\hline Gastropoda & & & 0.01 & & & & & \\
\hline \multicolumn{9}{|l|}{ Mytilidae } \\
\hline Perna perna & 0.02 & & 0.02 & & 0.01 & & & \\
\hline Ostreidae & & & 0.01 & & & & & \\
\hline OSTEICHTYES & 0.04 & 0.02 & 0.04 & 0.02 & 0.01 & & & \\
\hline \multicolumn{9}{|l|}{ Gobiidae } \\
\hline B. soporator (eggs) & & & 0.01 & & 0.01 & & & \\
\hline B. soporator (larvae) & & & 0.01 & & & & & \\
\hline Scales & 0.05 & 0.01 & 0.02 & & & & & \\
\hline ORGANIC MATTER & 0.18 & 0.04 & 0.10 & 0.01 & 0.34 & 0.15 & 0.35 & 0.13 \\
\hline SAND & 0.17 & 0.04 & 0.18 & 0.04 & 0.03 & 0.02 & 0.03 & 0.01 \\
\hline VOLUME TOTAL & & 79.56 & & 130.94 & & 180.69 & & 189.26 \\
\hline
\end{tabular}

Table 3. Result of the PERMANOVA (one-way) analysis for dietary differences between genders and periods.

\begin{tabular}{lccccc}
\hline \multicolumn{1}{c}{ Males vs. Females } & Df & Sum 0f Sqs & R2 & F & $\operatorname{Pr}(>$ F) \\
\hline Model & 1 & 0.263901 & 0.86461 & 12.772 & 0.3333 \\
Residual & 2 & 0.041325 & 0.13539 & & \\
Total & 3 & 0.305226 & 100.000 & & \\
\hline $\mathbf{1 9 9 7 - 1 9 9 8}$ vs. 2005-2006 & Df & Sum 0f Sqs & R2 & F & $\operatorname{Pr}(>$ F) \\
\hline Model & 1 & 0.010947 & 0.03587 & 0.0744 & 1 \\
Residual & 2 & 0.294279 & 0.96413 & & \\
Total & 3 & 0.305226 & 100.000 & & \\
\hline
\end{tabular}

Table 4. Trophic categories and feeding index (\%) in the Bathygobius soporator diet from Saco da Fazenda, Itajaí, SC, Brazil.

\begin{tabular}{lcccc}
\hline \multirow{2}{*}{ Trophic categories } & \multicolumn{2}{c}{ 1997-1998 } & \multicolumn{2}{c}{ 2005-2006 } \\
\cline { 2 - 5 } & Male & Female & Male & Female \\
\hline Algae & 96.71 & 92.68 & 89.0 & 91.14 \\
Crustacea & 1.85 & 6.63 & 2.4 & 1.26 \\
Polychaeta & 0.19 & 0.28 & 1.1 & 0.26 \\
Bivalvia & 0.05 & 0.06 & 0.01 & 0.05 \\
Osteichtyes & 0.14 & 0.19 & 0 & 0 \\
Scales & 0.06 & 0.01 & 0 & 0 \\
Organic matter & 1.00 & 0.15 & 7.49 & 7.29 \\
\hline
\end{tabular}

rator, with their respective frequencies of occurrence and volume oscillating between the periods sampled (Table 2). In 1995-1996, the green algae (Ulva fasciata) was the most common food item found, occurring in $72 \%$ of males and $64 \%$ of females, occupying a relative volume of $77.7 \%$ and $71.0 \%$, respectively. For the 2005-2006 samples, brown algae (Phaeophyta) was the most common food resource, representing $51.0 \%$ (males) and $48.0 \%$ (females) stomachs contents, with a relative volume of $50.6 \%$ and $65.4 \%$ respectively. The PERMANOVA analysis (Table 3 ) did not show significant differences between the diets of males and females $(F=0.07 ; p=1)$, as well as between sampling periods $(F=12.77 ; p=0.34)$.

The 38 items were grouped into seven trophic categories (Table 4), using the feeding index (IAi) and resulting in the item algae as main food resource. Crustacea, organic matter, Polychaeta and Bivalvia appears as secondary items while the other components of the fish's diet (such as sand, eggs and B. soporator's larvae) were considered to be accidental/occasional.

\section{DISCUSSION}

Bathygobius soporator proved to be an abundant species in the Santa Catarina estuarine environment. Due to the collection method used, we represented the species in classes larger than 4.5 centimeters. Larval stages were not represented, despite well represented immature stages. Thus, the species was not evaluated from an ontogenetic point of view.

Sex-ratio variations of the bi-monthly samples are within the patterns determined by Nikolsky (1969) and Vazzoler (1996), where the consequences of these oscillations are usually attributed to the environment and 
intrinsic factors of the species such as growth, mortality and behavior, which act differently between the sexes.

The growth parameters $L \infty$ and $K$ estimated for Bathygobius soporator indicate that it is a species of rapid development, reaching, on average, its asymptotic size in less than five years. The growth speed may be associated with inter-specific relationships. The environments where these species live may present a great tension caused by hydrodynamics, which exposes the species to competition and predation (Graham et al., 1985). In this way, rapid growth would ensure the perpetuation and establishment of the species in the environment.

The length-weight relationship showed a significant difference in allometric growth of $B$. soporator, with males showing a more significant increase in weight and length than females, indicating sexual dimorphism concerning growth. The $b$ values were within the limits of 2.4 to 4.0, registered in most of the fish species studied (Vazzoler, 1996; Froese, 2006). The oscillations in the allometric coefficient values are generally attributed to the environmental conditions and intrinsic biogenetic aspects of the species (Bolognini et al., 2013), which may explain this parameter's variation between the seasons. The higher body proportion of males concerning females is also an adaptation to territoriality and sexual selection, in which reproductive success depends on this trait.(Gross \& Sargent, 1985; Mendes, 2006).

The value for the first gonad maturation $\left(L_{50}\right)$ may be highly variable and unstable within a species depending on time, resources availability, temperature, photoperiod and other environmental abiotic factors (Nikolsky, 1969; Wootton, 1991; Vazzoler, 1997). Thus, the $L_{50}$ size in the population of $B$. soporator sampled on the coast of Rio de Janeiro - Brazil resulted in $5.0 \mathrm{~cm}$ of standard length (Nascimento \& Peret, 1986). In our study, all specimens caught under $6.5 \mathrm{~cm}$ in total length were immature, with the mean $L_{50}$ being around 8.16 in females and $10.31 \mathrm{~cm}$ in males. These first maturation sizes were similar between the sampled periods. When interpolated to the growth curves, it is estimated that maturation occurs before the first year of life of this species. Differences in first maturation sizes between males and females may result from growth rates and reproductive tactics between the two sexes. In B. soporator, males allocate more energy for body development, improving the offspring's reproductive success and parental care.

High GSI values show an increase in reproductive behavior in summer, in both our sampling periods, a similar pattern detected by Carvalho-Filho (1999) and Mendes (2006) for other species of gobies. In general, gonadal development may be stimulated by photoperiod increase combined with rising temperatures and other abiotic factors (Jonassen et al., 2000) characteristic of warmer seasons.

The analysis of the stomach contents for both sexes revealed the predominance of Ulva fasciata in 1997-1998 and the Rhodophyta group for 2005-2008 in all months, unlike the results found by Soares et al. (2016), which recorded the dominance of crustaceans for this species diet and considered the accidental ingestion of algae, as a consequence of the cleaning of the nesting areas by $B$. soporator males. Besides, the organic matter, crustaceans and polychaetes alternated in importance between the periods in the species' diet. The presence of organic matter in the stomach contents may be due to a constant habit of foraging and prolonged activity (Hahn et al., 1999; Soares et al., 2016), while crustaceans and polychaetes are recurrent and important items in the diet of demersal fish (Turra et al., 2012). However, our study is the first to report the presence of polychaetes in the stomachs of the $B$. soporator, despite being a frequent item in other gobies (Køie et al., 2004).

The occurrence of sand in B. soporator's stomachs reinforces the benthic habit of this species. The sand can be eaten accidentally in the preparation and, along with their eggs and larvae, in nest maintenance and parietal care. The scales ingested can be either a reflection of their aggressive territorial behavior or a piscivorous habit already recorded in other studies (Tavolga, 1954; Soares et al., 2016). Some studies suggest an intra-specific competition in gobids, where the best nests are conquered through aggression and egg removal among individuals (Nellbring; Magnhagen; Wilson \& Turelli, 1986).

This study's results highlight the ecological role of B. soporator on the Brazilian coast and are similar to the ones found by Nascimento \& Peret (1986) and Lopes \& Oliveira-Silva (1998). Thus, the specific differences of the food items reported here and in other studies may reflect local environmental conditions, where the species tends to optimize its foraging (MacArthur \& Pianka, 1966), minimizing energy expenditure and using it for growth, reproduction and parental care.

Bathygobius soporator showed sexual dimorphism, with males reaching larger body sizes than females. A difference was observed between males' allometric coefficient in the two periods, being negative allometric (1997-1998) and isometric (2005-2006). In contrast, females presented negative allometric type growth in both periods, with b value always lower than males. In addition, the intensification of the reproduction period occurred in the spring and summer months, a reflection of the increase in the gonadosomatic index (GSI). Finally, algae were the most important item in the diet for both sexes and periods, where Ulva fasciata and Rhodophyta group contributed with the largest portion of the diet in 1997-1998 and 2005-2006 samples periods. Bathygobius soporator presented high trophic plasticity and can be classified as omnivorous-opportunistic.

\section{ACKNOWLEDGMENTS}

The authors would like to thank biologist Cristiano Lombardo Evangelista, oceanographers Jurandir Joaquim Bernardes Júnior and Francine Corrêa Manoel for their assistance in the field and laboratory work. The School of the Sea Science and Technology of the University of Vale do Itajaí, for supporting research, CNPq (National Research Council) and CAPES (Coordination and Improvement of Higher Level or Education Personnel), for the research grants awarded to authors. 


\section{AUTHORS' CONTRIBUTIONS}

All authors actively participated in discussing the results, reviewed and approved the final version of the article. G.H.C.B.: conceptualization, methodology, software, formal analysis, investigation, original draft, writing, review \& editing and validation; J.G.V.: investigation, methodology and writing, review \& editing and validation; G.S.P.: writing, review \& editing and validation; J.O.B.: conceptualization, writing, project administration, supervision, resources, review \& editing and validation.

\section{REFERENCES}

Anderson, M.J. 2001. A new method for non-parametric multivariate analysis of variance. Austral Ecology, 26: 32-46.

Berg, J. 1979. Discussion of methods of investigating the food of fishes, with a reference to a preliminary study of the prey of Gobiusculus flavencens (Gobiidae). Marine Biology, 50: 263-273.

Bolognini, L.; Domenichetti, F.; Grati, F.; Polidori, P.; Scarcella, G. \& Fabi, G. 2013. Weight-length relationships for 20 fish species in the Adriatic Sea. Turkish Journal of Fisheries and Aquatic Sciences, 13(3): 563-568.

Carvalho-Filho, A. 1999. Peixes: Costa Brasileira. São Paulo, Editora Melro. $320 \mathrm{p}$.

Froese, R. 2006. Cube law, condition factor and weight-length relationships: history, meta-analysis and recommendations. Journal of Applied Ichthyology, 22(4): 241-253.

Graham, J.B.; Jones, C.B. \& Rubinoff, I. 1985. Behavioural, physiological, and ecological aspects of the amphibious life of the pearl blenny Entomacrodus nigricans gill. Journal of Experimental Marine Biology and Ecology, 89: 255-268.

Gross, M.R. \& Sargent, R.C. 1985. The evolution of male and female parental care in fishes. American Zoologist, 25(3): 807-822.

Hahn, N.S.; Loureiro, V.E. \& Delariva, R.L. 1999. Atividade alimentar de curvina Plagioscion squamosissimus (Heckel, 1840) (Perciformes, Sciaenidae) no rio Paraná. Acta Scientiarum, biological sciences, Maringa, Pr., 21: 309-314.

Hammer, Ø.; Harper, D.A.T. \& Ryan, P.D. 2001. PAST: Paleontological Statistics software package for education and data analysis. Palaeontologia Eletronica, 4(1): 1-9.

Hynes, H.B.N. 1950. The food of freshwater sticklebacks (Gasterosteus aculeatus and Pygosteus pungitius) with a review of methods used in studies of the food of fishes. Journal Animal Ecology, Oxford, 19: 36-58.

Jonassen, T.M.; Imsland, A.K.; Kadowaki, S. \& Stefansson, S.0. 2000. Interaction of temperature and photoperiod on growth of Atlantic halibut Hippoglossus hippoglossus. Aquaculture Research, 31(2): 219-227.

Kawakami, E. \& Vazzoler, G. 1980. Método gráfico e estimativa de índice alimentar aplicado no estudo de alimentação de peixes. Boletim do Instituto Oceanográfico, 29(2): 205-207.

Køie, M.; Whipps, C.M. \& Kent, M.L. 2004. Ellipsomyxa gobii (Myxozoa: Ceratomyxidae) in the common goby Pomatoschistus microps (Teleostei: Gobiidae) uses Nereis spp. (Annelida: Polychaeta) as invertebrate hosts. Folia Parasitologica, 51(1): 14-18.

Kovacic, M. 2007. Reproductive biology of the striped goby, Gobius vittatus (Gobiidae) in the northern Adriatic Sea. Scientia Marina, 71(1): 145-151.

Le Cren, E.D. 1951. The length-weight relationship and seasonal cycle in gonadal weight and condition in the perch (Perca fluviatilis). Journal of Animal Ecology, 20(2): 201-219.
Lopes, P.R.D. \& Oliveira-Silva, J.T. 1998. Alimentação de Bathygobius soporator (Valenciennes, 1837) (Actinopterygii: Teleostei: Gobiidae) na localidade de Cacha Pregos (Ilha de Itapatica), Bahia, Brasil. Biotemas, 11: 81-92.

MacArthur, R.H. \& Pianka, E.R. 1966. On optimal use of a patchy environment. The American Naturalist, 100(916): 603-609.

Manoel, F.C.; Branco, J.0. \& Barbieri, E. 2011. Composição da avifauna aquática do Saco da Fazenda, Itajaí, SC. O Mundo da Saúde, 35(1): 31-41.

Mendes, L.F. 2006. História natural dos amborés e peixes-macaco (Actinopterygii, Blennioidei, Gobioidei) do Parque Nacional Marinho do Arquipélago de Fernando de Noronha, sob um enfoque comportamental. Revista Brasileira de Zoologia, 23(3): 817-823.

Menezes, N.A. \& Figueiredo, J.L. 1985. Manual de peixes marinhos do sudeste do Brasil. V. Teleostei (4). São Paulo, Museu de Zoologia da Universidade de São Paulo.

Nascimento, M.T. \& Peret, A.C. 1986. Reprodução e Nutrição de Bathygobius soporator (Cuvier and Valenciennes, 1837) do Canal do Itajuru, Cabo Frio - RJ (Perciformes - Gobioidei - Gobiidae). Ciência e Cultura, São Paulo, 38(8): 1404-1413.

Nellbring, S. 1986. A quantitative and experimental study of goby (Pomatoschistus spp.) nests on a shallow soft bottom, northern Baltic proper. Ophelia, 25(1): 15-23.

Nelson, J.S.; Grande, T.C.; Wilson, M.V. 2016. Fishes of the World. 5. ed. New York, John Wiley \& Sons.

Nikolski, G.V. 1969. Theory of fish population dynamics: as the biological background for rational exploitation and management of fishery resources. Edinburgh, Oliver \& Boyd.

Paiva, A.C.G.; Chaves, P.T.C. \& Araújo, M.E. 2008. Estrutura e organização trófica da ictiofauna de águas rasas em um estuário tropical. Revista Brasileira de Zoologia, 25(4): 647-661.

Sabinson, L.M.; Rodrigues-Filho, J.L.; Peret, A.C.; Branco, J.0. \& Verani, J.R. 2015. Feeding habits of the congeneric species Stellifer rastrifer and Stellifer brasiliensis (Acanthopterygii: Sciaenidae) co-occurring in the coast of the state of Santa Catarina, Brazil. Brazilian Journal of Biology, 75(2): 423-430.

Santos, E.P. 1978. Dinâmica de populações aplicada à pesca e piscicultura. São Paulo, HUCITEC/EDUSP.

Soares, B.E.; Lobato, C.M.C.; Freitas, D.T.H.; Oliveira-Raiol R.D. \& Montag, L.F.A. 2016. Sex differences on the feeding of the gobiid fish Bathygobius soporator in tide pools of Maiandeua Island, Pará, Brazil. Iheringia, Série Zoologia, 106: 1-4.

Tavolga,W.N. 1954. Reproductive behavior in the gobiid fish Bathygobiussoporator. Bulletin of the American Museum of Natural History, 104(5): 427-446.

Turra, A.; Santos, F.B.; Bessa, E.; Fernandez, W.S.; Bernadochi, L.C. \& Denadai, M.R. 2012. Population biology and diet of the southern kingcroaker Menticirrhus americanus (Linnaeus, 1758) (Perciformes: Sciaenidae) in Caraguatatuba Bay, southeastern Brazil. Brazilian Journal of Oceanography, 60(3): 343-352.

Vazzoler, A.E.A.M. 1996. Biologia da reprodução de peixes teleósteos: teoria e prática. Maringá, Eduem. 169 p.

Vazzoler, A.E.A.M. 1997. A planície de inundação do alto rio Paraná: aspectos físicos, biológicos e socioeconômicos. Maringá, Eduem. 460p.

von Bertalanffy, L. 1938. A quantitative theory of organic growth (inquiries on growth laws. II. Human biology, 10(2): 181-213.

Wilson, D.S. \& Turelli, M. 1986. Stable underdominance and the evolutionary invasion of empty niches. The American Naturalist 127(6): 835-850.

Wootton, R.J. 1991. Ecology of teleost fishes. Fish and Fisheries. London, Chapman and Hall.

Zanlorenzi, D. \& de Tarso Chaves, P. 2011. Alimentação de Ctenogobius shufeldti (Jordan e Eigenmann, 1887) (Teleostei, Gobiidae) na Baía de Guaratuba, Atlântico oeste subtropical. Biotemas, 24(1): 37-46. 